This item was submitted to Loughborough's Research Repository by the author.

Items in Figshare are protected by copyright, with all rights reserved, unless otherwise indicated.

\title{
Reflections on doing the expat show: performing the global mobility industry
}

PLEASE CITE THE PUBLISHED VERSION

http://dx.doi.org/10.1068/a46249

\section{PUBLISHER}

(C) Pion

\section{VERSION}

AM (Accepted Manuscript)

\section{PUBLISHER STATEMENT}

This work is made available according to the conditions of the Creative Commons Attribution-NonCommercialNoDerivatives 4.0 International (CC BY-NC-ND 4.0) licence. Full details of this licence are available at: https://creativecommons.org/licenses/by-nc-nd/4.0/

\section{LICENCE}

CC BY-NC-ND 4.0

\section{REPOSITORY RECORD}

Cranston, Sophie. 2019. "Reflections on Doing the Expat Show: Performing the Global Mobility Industry". figshare. https://hdl.handle.net/2134/16392. 
Cite as: Cranston S, 2014, "Reflections on doing the Expat Show: performing the Global Mobility 1 Industry" Environment and Planning A 46(5) 1124 - 1138, doi:10.1068/a4624

Title: Reflections on Doing the Expat Show: Performing the Global Mobility Industry

Corresponding Author:

Sophie Cranston, University of Edinburgh

Email address: sophie.cranston@ed.ac.uk

Postal address: Institute of Geography, Drummond Street, Edinburgh, EH8 9XP 


\section{Title: Reflections on Doing the Expat Show: Performing the Global Mobility Industry}

Abstract: This paper argues that we need to pay more attention to the spaces in which the (knowledge) economy operates and industry sectors are brought into being. Following research that examines the performative nature of the economy (for example Barnes, 2008; Gregson, 2011; MacKenzie, 2006; Mitchell, 2008; Thrift, 2005) the paper sees the trade show as not merely a reflection of an industry sector, but a space that produces it into being. Looking at the Global Mobility Industry, an industry directed towards the management of expatriates, the paper uses narratives to uncover performance as way to understand the practice of knowledge, specifically benchmarking about talent management, at the Expat Show.

\section{Key words: Trade Shows, Global Mobility Industry, Expatriate, Talent Management, Performativity}

\section{Introduction: Going In}

In the lobby of a London Hotel. The small waiting area opposite reception is overflowing, filled with tourists and business men and women. Past the reception room, there is a queue of people waiting impatiently to be registered. There is a lowlevel of murmuring noise. The registration table is covered with hundreds of name badges, detailing names and companies. You are handed this along with a programme and a bag full of brochures from the sponsors upon registering. Once past registration, everything becomes much louder and busier. Some attendees are here with colleagues, others on their own. They greet each other warmly: how are you? What are you doing here? A reccy round the show finds exhibitors geared up, reading the name badges going by, trying to catch the passer-by's eye, lots of 
Cite as: Cranston S, 2014, "Reflections on doing the Expat Show: performing the Global Mobility 3 Industry" Environment and Planning A 46(5) 1124 - 1138, doi:10.1068/a4624

exaggerated smiles. The stalls are laid out to entice, adorned with brightly coloured images, brochures are laid out on tables, adverts for prize-draws, freebies are clearly shown. Big flat screen TV's display the programme for the day and highlight the main sponsors. The overhead announcer cuts through the noise by advertising the seminar programs to be held throughout the day. (Narrative 1. Observations on Going into Show, Field Notes, 2011).

Trade shows, variously called trade fairs, exhibitions, or expos, are one to five day events targeting a similar audience. The trade show in the narrative, the Expat Show, was a showcase of the Global Mobility Industry, hereafter GMI, an industry that directs itself at the management of expatriates. Trade shows act as an arena in which the latest trends, products, services and opportunities within an industry are presented. The Expat Show that I attended was an opportunity for the GMI to publicise and sell their services to their potential transnational organisation clients. It was advertised as 'everything HR need to plan and manage their expatriate programmes' (Email Advertising, May 2010). However, this paper argues that trade shows can be seen as an indicative space through which an industry organises, is enacted and comes into being. It views the trade show as being both 'a temporary material space in which transnational business is taking place' (Jones, 2009 210) and as a learning space in the circuits of knowledge capitalism (Thrift 2005).

In doing so the paper makes three arguments. First, that we need to pay more attention to the multiple and different sites of the economy, the trade show being one of them. This takes its lead from organizational theory which has witnessed an empirical and epistemological move away from organisations being understood as 'objective, concrete, material and unproblematic entities' (Schwartzmann, 1993 36). 
Instead, there is a focus on organising, 'the processes out of which a sense of organization unfolds and is enacted' (Schwartzmann, 1993 36). Thus it argues that organisations should not be seen as operating in a demarcated, bounded space, but as being multiple, mobile and messy. This leads us to think about the sites in and through which organisations and industries operate, and 'how organisational spaces are brought into being' (Conradson, 2003 1975). As the opening narrative begins to illustrate, the Expat Show acts as a site in which organisations selling services, and representatives from organisations wanting to purchase these services, come together in a space outside the confines of the office.

Second, the paper argues that the trade show provides us with a space through which we can understand the importance of performance within the economy. This allows us to see the economy as being something that is practised. As Jones and Murphy highlight in their paper on practice in economic geography, focusing on practice helps us understand the role of 'people living, laboring, and creating in the everyday economy' (2011 376)- that practice is made through performance. The paper will argue that this focus on the way in which the economy is practiced helps us understand how knowledge and knowledge industries, such as the GMI are constituted and produced in business spaces like the trade show. It sees the trade show as an 'event which depend[s on]... their very existence for their bring into being, on specific performances' (Gregson and Rose, 2000 434). As the opening narrative shows for the Expat Show these 'specific performances' are of the service provider, the show organiser and the customer that turn the hotel venue room into a trade show, and a collection of often distinct and disparate organisations into an industry (c.f. Mitchell, 2008; MacKenzie, 2006). For example, the attempts to entice the passer-by through fake smiles, freebies and prizes deemed suitable for a corporate audience are 
part of a packaging both about what the industry is and does and who its customer should be. The paper will argue that these performances enable the practice of knowledge in particular ways.

Third, I argue that the methodological approach to understanding cultural circuits of capital do not seem to have kept up with the reimagining of the economic. In cultural economic geography I argue that Yeung's statement continues to have resonance, that "The practicalities of what it means to "do" new economic geographies are still unclear and remain underdeveloped' (2003 442). The opening narrative begins to illustrate some of the experience of being there, of observing, taking part, chatting, networking at the show. In the paper, I follow other work in cultural economy (Gregson, 2009; 2011; Swanton, 2013) that advances a case for the use of narratives for understanding how knowledge is practised within cultural circuits of capital.

With these arguments in mind, the next section will provide contextual information on the GMI. Section three will look at how practice and performance can be understood in the context of knowledge industries. Section four provides a methodological account of the Expat Show. Section five examines how knowledge is practiced at the Expat Show, using benchmarking as an example, arguing that the performances work to stabilize and in turn perform particular understandings of talent management.

\section{The Global Mobility Industry}

The expatriate is a common nomenclature denoting a highly skilled migrant who lives temporarily overseas. The small, but growing, amount of research that looks at this type of mobility focuses on how expatriate's lives play out in place. This 
research focuses on both the everyday negotiations of attachment and belonging (see for example Walsh, 2006) and the operation of expatriates as conduits of globalisation, as part of global flows and global cities (for example Beaverstock, 2002; 2005; Faulconbridge, 2010). This second area of research on expatriates looks at knowledge accumulation and dissemination and the effect of this on the transnational organisation and economy. Yet while much of this research considers corporate expatriates, that is inter-company transfers, it tends not to consider the ways in which this form of mobility is produced by transnational organisations, as Millar and Salt highlight: 'the ways in which companies orchestrate, acquire and deploy their networks of expertise internationally in response to changing opportunities are poorly understood' (2008 27). That is to say the human resource management practices of the transnational organisation, in which the GMI is involved, impact upon the way in which expatriation plays out in place.

The GMI directs itself at assisting in the management of expatriates, targeting international human resource management (IHRM) professionals as opposed to expatriates directly. The industry therefore acts as an outsourcer for IHRM processes associated with the global movement of expatriates within transnational organisations. The day-to-day activity of the industry involves assisting with the relocation of individuals and their families. The GMI provides services in immigration, tax compliance, relocation management, accommodation services, household goods removal and cross-cultural training. The industry self-reports to be worth $\$ 500$ billion (Event Advertising Material, November 2011).

Some companies within the GMI offer a full array of services for expatriate management. These are relocation management companies such as Santa Fe Relocation Management, Crown Worldwide Relocation, the MI Group. Other 
companies within the GMI specialise in one service, such as Farnham Castle, Communcaid and Net Expat who offer cross-cultural training. The industry has recently undergone a number of mergers, with for example, Santa Fe acquiring European relocation management leaders Interdean in 2011. However, while companies like Santa Fe have 122 offices in 52 countries (www.santaferelo.com, accessed 1/4/2013), there are many individuals that consider themselves part of the GMI who offer specialised services from home offices. Due to the diversity of types of organisations within the industry, it may be more accurate to describe it as a set of industries. However, the larger and smaller organisations within the industry are intertwined. Often, larger companies utilise supply chains to outsource functions to smaller companies.

The industry-specific Expat Show which forms the empirical basis of this paper therefore can be seen to provide a lens through which we can see the European Global Mobility market. The paper now turns to how we can theorise that this happens.

\section{Practising/Performing the Knowledge Economy}

The paper uses performance to understand the practice of knowledge at the Trade Show. In doing so, it helps to address how economic geography can move off the 'sidelines' (Berndt and Boeckler 2011 544) in the wider pragmatic turn of the social sciences of markets. This pragmatic turn, drawing upon ideas from Law, Latour and Callon, highlights how practices enabled by socio-technological arrangements lead to the 'self-realization of economic knowledge' (Berndt and Boeckler, 2009 537). Rather than treating people as passive within the production of the economic, this enables us to consider the central role of people and objects in the practice of 
knowledge at the trade show. It therefore presents a shift in thinking in researching economic geographies of knowledge, by foregrounding the role of practice in spaces of the economy, addressing the issue that 'the economic performativity literature has had no real impact on the theory or practice of either economic geography' (Christophers, 2012 2543). As section 3.1 will illustrate, whilst research on the geographies of knowledge begins to illustrate how knowledge can be practised in distinct spaces of the economy, it misses an understanding of how this knowledge is based on the performance of people and is in itself performative. Research in the knowledge economy on the other hand has resulted in rich understandings of the performativity of knowledge, as 3.2 shows, but in its focus on organization and formal education spaces, means that we miss an understanding of how this is practised.

\subsection{Practising Knowledge}

Jones and Murphy outlining understandings of practice within economic geography, define practice as 'the stabilized, routinized, or improvised social actions that constitute and reproduce economic space, and through and within which diverse actors... and communities...organize materials, produce, consume, and/or derive meaning from the economic world' (2011 363). They argue that practice marks 'an important innovation in economic geography thinking' (Jones and Murphy, 2011 363) and offer a three-part epistemological origin of the ways in which practice can be understood- governance and structural approaches, communication and performance approaches and learning and collective knowledge approaches. Through this we can see that understandings of practice are not in themselves new. In particular, research 
that looks at the geographies of knowledge draws upon Polanyi's distinction of explicit and tacit forms of knowledge to look at how different types of knowledge can be transferred- or practised- across different spaces and scales (Gertler, 2003; Maskell et al., 2006; Coe and Bunnell, 2003). In this research, the spatiality of knowledge transfer practices are central. This provides us with accounts of the practices of knowledge within spaces like the trade show.

Maskell, Bathelt and Schuldt's (2006) research specifically highlights how trade shows act as temporary spaces of knowledge creation and exchange (also Bathelt et al., 2004; Bathelt and Schuldt, 2010; Schuldt and Bathelt, 2011). For example, Bathelt and Schuldt argue that "trade fairs, which enable physical colocation and personal contact of economic agents, have become important temporary platforms of knowledge exchange and networking by making connections regardless of spatial restrictions" (2010 1959). However, this research while offering insights into what happens in these spaces, misses an understanding of performance in two ways. First, it often neglects the role that both people and objects play in the practice of knowledge. As research in the pragmatic turn highlights markets are produced through human and non-human actors. Material objects and people are present in networks of relations through which the economic is performed. Benuza and Stark (2004) in looking at the socio-technology of arbitrage in Wall Street trading rooms show how the market is practised through a combination of equations, connectivity, computing and the spatial configurations of the particular locale. Second, research in the geography of knowledge does not connect these practices to the operation of specific industries. As Schuldt and Bathelt (2011 3) themselves suggest, 'buzz' (or face-to-face contact (c.f. Storper and Venables, 2004)) unfolds in 'different practices and varies according to the purpose and business context of a trade fair.' Therefore, 
Cite as: Cranston S, 2014, "Reflections on doing the Expat Show: performing the Global Mobility 10 Industry" Environment and Planning A 46(5) 1124 - 1138, doi:10.1068/a4624

the literature on the geographies of knowledge, while illustrating the spatiality of knowledge practices, misses understandings of how this knowledge is performed and performative.

\subsection{Performing Knowledges}

Following research that utilises actor-network theory, we can suggest that 'performance means that the very act itself creates the reality that it describes' (Barnes, 2002 508). However, existing research on knowledge industries takes its main inspiration from Thrift's cultural circuits of capitalism as opposed to STS studies (see for example Hall, 2007; Faulconbridge, 2007; 2010). While these approaches are complimentary, the focus on the circulation of knowledge as performance means that often we miss an understanding of how this knowledge is practised.

Thrift defines cultural circuits of capital as 'the continuous production of propositional and prescriptive knowledge, [which] has the power to make its theories and descriptions of the world come alive in new built forms, new machines and new bodies' (Thrift, 2005 11). The knowledge upon which these industries are based on, actively participate in producing the economies that they are seen to report- they are performative. The work that draws upon cultural circuits of capital provides accounts of the production, circulation and dissemination of knowledge. For example, Hall's research on business education uses the concept of 'ecologies' to consider how the circuit of business knowledge has a 'co-constitutive relationship' between spaces of the classroom and firm (Hall, 2009 605). What this illustrates is that cultural circuits 
Cite as: Cranston S, 2014, "Reflections on doing the Expat Show: performing the Global Mobility 11 Industry" Environment and Planning A 46(5) 1124 - 1138, doi:10.1068/a4624

of capital do not operate in a linear way between theory and practice, that the knowledge that these circuits operate on differs between spaces.

Yet, what is missing from many accounts of the knowledge economy is a look at how knowledge is practised in spaces outwith those of the organization or formal education- the trade show being one of them. This means that we miss an understanding of how knowledge is practised in other spaces of the knowledge economy- the socio-technological arrangements that enable cultural circuits of capital. As Mitchell shows in his examination of the 'invention' of light bulbs by Edison, 'economic knowledge does not represent the economy from some place outside. It participates in making sites where its facts can survive' (Mitchell, 2008 1116). In the context of light bulbs, Mitchell suggests that its invention was also an invention of the need, desire and apparatus to support the light bulb.

What this section illustrates is a need to see the trade show as a space in which knowledge is practised. It sees practice as being made up of the performances of the vendors, attendees and show organisers and objects that make up the show, the set up of the seminars, the vendor stalls and the advertising materials. The performances of people and objects allow us to see how knowledge is transferred at the Expat Show. However, the Expat Show can be seen as not only as a space in which knowledge is practised, but one through in which this knowledge works to perform an industry. So while this paper will demonstrate how knowledge, in this case knowledge about talent management, is transferred through the performances of people and objects, these performances also produce a need for the GMI within talent management practices. It argues the Expat Show is not merely a reflection of the GMI, but works to produce the industry into being. 
Cite as: Cranston S, 2014, "Reflections on doing the Expat Show: performing the Global Mobility 12 Industry" Environment and Planning A 46(5) 1124 - 1138, doi:10.1068/a4624

\section{Trade Show Methodology}

Although cultural economic and pragmatic approaches have reconfigured how we understand the economic, the methodological impulse has not kept up. The focus, within much qualitative economic geography, is that of key player or corporate interviews, that 'venturing beyond interviews is not as commonplace as it might be' (Barnes et al., 2007 33). However, as McCann $(2011,117)$ suggests in his call for an ethnography of policy 'something happens to policy knowledge along the way, in the telling, and on sites.' This means to understand practice at events like the trade show, we need to employ methods like participant observation to capture how knowledge is practised in the telling. The paper therefore provides an example of 'how conferences might be studied ethnographically’ (McCann, 2011 123).

Participant observation at the show enabled an understanding of the subtleties of human interaction, rather than just how interactions were represented or discussed (c.f. Faulconbridge, 2010). It allows for an account of both what was being said at the Expat Show, with an account of how it was being said. However, the form of participant observation is different from the ethnographic immersion that is usually touted by methodological textbooks (e.g. Cook 2005). The Expat Show lasted 8 hours, participant observation became as much as simply being there and taking partobserving, asking questions, discussing global mobility issues, passing by, overhearing, attending seminars and collecting leaflets- becoming a member of, and taking part in, the crowd. ${ }^{1}$ Rather than formal interviews, informal interviews or 'chats' were used that would include questions of global mobility trends, services that

\footnotetext{
${ }^{1}$ In terms of triangulation, the results have been corroborated with interviews with GMI service providers, IHRM managers, participation and assistance at other GMI events and industry data.
} 
Cite as: Cranston S, 2014, "Reflections on doing the Expat Show: performing the Global Mobility 13 Industry" Environment and Planning A 46(5) 1124 - 1138, doi:10.1068/a4624

their company offered and their motivations for attending the trade show. Similar conversations were held with other attendees at the show who were IHRM managers. This observation and participation allows the researcher to see 'gestures, speech patterns or other embodied aspects of labour as they occur, and to ask questions about these practices in situ' (McMorran, 2012 491).

However, thinking about how events might be studied ethnographically, also calls into question the ways in which we write up accounts of spaces like the trade show. This means as well as presenting our research through excerpts from transcripts, we need to explore alternative formats. This paper takes a lead from Gregson's work on materiality and ship disposal that argues 'the art of story-telling needs to be rekindled in cultural economy' (2009 297). She argues that to understand the material politics of ship disposal 'it requires finding a way of writing that places readers in the midst of the kinds of practices, doing, actions, becomings, unbecoming and open practices of mattering' (Gregson, 2011 143). Here, she shows that narratives place the reader among what that they are describing. Similarly, this paper uses narratives to bring together what people do, say and the objects that enable this.

The narratives presented are written up from comprehensive field notes taken at the Expat Show. These notes were handwritten throughout the day, with descriptions of what people were saying, doing and objects involved noted down at opportune moments. Effort was made to ensure that the notes taken reflected both parts of the Expat Show. One section saw vendors advertise and sell their products and services to the attendees from stalls. These stalls were the place where the direct sell happens, often being populated by sales representatives from the companies within the GMI. The other part of the trade show comprised a series of ongoing seminars, often held jointly between an exhibitor and their clients. At twenty minutes 
Cite as: Cranston S, 2014, "Reflections on doing the Expat Show: performing the Global Mobility 14 Industry" Environment and Planning A 46(5) 1124 - 1138, doi:10.1068/a4624

long, they provided the vendors an opportunity to explain in detail about the product and services that their company offered. Once the event was finished, these notes were then used as a memory aide as 'an account of the participant observation experience- making a story of what you learned out of the fragments you have' (Cook 2005 181). The narratives therefore present a selection of 'tales from the field' (Van Maanen 2011), being a write up of coherent stories from more complex data.

As with other ethnographic research the narratives here can be subject to questions of reliability and representation. Cultural economic approaches must 'acknowledge the contingent, open-ended, and situated nature of the dynamic realities which firm our 'objects' of study, along with the unavoidable positionality of researchers and the situatedness of their knowledge claims' (James et al., 2007 5). In terms of my positionality, in common with all participants, I wore a badge that displayed my institution. This emphasized my 'outsider' positionality- often leading attendees to take on a teacher role, educating me on how the industry works. By 2012, having done three years of research in the field, I was recognizable to the attendees at the Expat Show which enabled me to take more of an insider role within its general sociability.

Returning to James (2007), cultural economic approaches can be seen as situated and contingent. The narratives presented in this paper do not claim to be universal for all trade shows. Each show was marketed as the being the 'European' version of the trade show and was held in London. The show was organized by a UKbased global mobility group that provides support and education for IHRM professionals. In terms of European trade shows for the GMI, this event is one of three (two in London, one in Paris) held annually that are free for corporate HR professionals to attend. Throughout the year there are also global mobility summits 
Cite as: Cranston S, 2014, "Reflections on doing the Expat Show: performing the Global Mobility 15 Industry" Environment and Planning A 46(5) 1124 - 1138, doi:10.1068/a4624

and symposiums with similar vendors and IHRM professionals present. The vendors at the Expat Show represent the larger European firms, or European offices of transnational firms, but almost all have a global outreach of service provision. ${ }^{2}$ In 2010, there were 62 vendor stalls and 22 seminars with 800 corporate HR and other GM professionals registered to attend the event (Email Advertising, February 2011). By 2012, this had increased to 130 vendor stalls and 25 seminars, with the event organisers estimating 800-1000 people would attend (Email advertising, April 2012).

\subsection{At the Show: Benchmarking}

The seminar is being held jointly between a representative from a cross-cultural training company and a representative from their client, a multinational engineering company. The topic is employee safety, specifically issues of security and culture. The cross-cultural trainer introduces the seminar, the client talks 'with her pleasure.' He anecdotally talks about the countries in which his company operates in and the problems they have faced. The emphasis he is placing is that cultural understanding is crucial to ensure security. This point is remade, repeated and emphasised. Then cross-cultural trainer returns. She suggests that we need to look at the 'talent' in our organisation, to test them using an international profiler to see how suitable and prepared they are to work overseas, to see whether they are good fit for the country they are going to, to develop their intercultural skills. The statistic on the PowerPoint slide behind her show that the majority companies that use cross-cultural training think it contributes to the success of their international assignments. (Narrative 2, Seminar by Consultant and IHRM manager, Cross Cultural Management Service, 2011).

\footnotetext{
${ }^{2}$ This is apart from those companies offering serviced accommodation who were often more local, particularly London-focused.

Cite as: Cranston S, 2014, "Reflections on doing the Expat Show: performing the Global Mobility Industry" Environment and Planning A 46(5) 1124 - 1138, doi:10.1068/a4624
} 
Cite as: Cranston S, 2014, "Reflections on doing the Expat Show: performing the Global Mobility 16 Industry" Environment and Planning A 46(5) 1124 - 1138, doi:10.1068/a4624

Narrative two illustrates the ways through which the conference room in the hotel become a space of business education (Hall, 2007). This is through the practices of people, objects and ideas. As pragmatic approaches to understanding the economy highlight 'markets are performative effects of complex embodied and concrete sociomaterial arrangements' (Barnes, 2008 1436). This means to understand the practice of knowledge, we look at the performances of the human and non-human. For example, Barnes in his examination of the performance of economic geography argues that 'performances are put on not only by humans, but also by objects' (2002 489). As the narrative illustrates the numbers being conveyed through statistics, the lecture like feel, is the technology that brings ideas into being. This I argue is the material manifestation of benchmarking, the way in which knowledge about talent management becomes tangible (c.f. Barnes, 2002).

Benchmarking, put simply, in this context is the comparison between one company's expatriate policy to another company's expatriate policy to see how they compare to the norm. This includes aspects of the policy such as levels of remuneration and benefits offered, for example housing and education allowances, cross-cultural training, family support, as well as what aspects of their expatriate management they outsource and to whom. The norm is calculated through the collection of information, often through surveys, about expatriate assignment policies. The results of these surveys are often presented at Global Mobility Events. However, benchmarking can be seen to a be a calculative practice. Callon defines calculative practices as not 'merely record[ing] a reality independent of themselves; they contribute powerfully to shaping it, simply by measuring it, the reality that they measure' (1998 23). As Larner and Le Heron show, benchmarking 'emphasises 
Cite as: Cranston S, 2014, "Reflections on doing the Expat Show: performing the Global Mobility 17 Industry" Environment and Planning A 46(5) 1124 - 1138, doi:10.1068/a4624

performativity' (2002 765)- it works not only to describe industry norms of expatriate management policy, but works to produce policies as companies adapt their policies to fit the norm, using benchmarking as justification. It is in this way that benchmarking can be seen as 'systems around which many global objects, subjects, and other relations are constructed' (Larner and Le Heron, 2002 760). However, rather than looking at the resulting performativity of benchmarking, this paper focuses on how benchmarking is practised at the Expat Show. Callon argues that for calculated decisions to be taken, the agent must be able to: 'a) draw up a list of possible world states; b) hierarchize and rank these world states; c) identify and describe the actions required to produce each of the possible world states' (1998 260). This 'drawing up of a list of possible world states' is one of the key practices of knowledge at the Expat Show. This section argues that this works in two ways, the staging of knowledge and through forms of sociability.

First, people and objects work to stage the knowledge at the Expat Show in a way that enables the practice of benchmarking. As narrative 2 shows the set-up of the conference room that results in the presentation of facts and figures, such as statistics about cross-cultural training are a way in which benchmarking happens as the attendees can write these numbers and bullet-points down. The PowerPoint slides, the projector can therefore be seen as objects that are part of knowledge practices. The knowledge of the best practices in expatriate assignment management is also performed through the seminar. This happens through the 'improvisational performances' of the people in the seminar (Crang, 1994). For example, the collaboration between the intercultural services provider and a representative from the transnational organization that they work with gives the presentation seemingly give the presentation a sense of legitimacy, a rubber stamp of approval from the consumer. 
Cite as: Cranston S, 2014, "Reflections on doing the Expat Show: performing the Global Mobility 18 Industry" Environment and Planning A 46(5) 1124 - 1138, doi:10.1068/a4624

The use of anecdotes can be seen as a tactic to try and make the talk more memorable. Combined, it works to give the seminar speakers authority to speak about talent management. These practices collectively illustrate how 'the drawing up of world states' is achieved through the performances of people and objects in the seminar sections of the Expat Show. This benchmarking also happens through networking, which narrative three illustrates.

After the seminar we are encouraged to go and have a look around the stalls-we can 'take advantage' of the networking opportunities and the exhibition. The seminars don't run back to back, there are breaks so there is time to talk to the vendors. Tea and coffee is set up in the middle of the floor, surrounded by the stalls. The tables and chairs fill up quickly; some people are having a meeting, others sitting on their own, frantically catching up on their emails while they are out of the office or trying to look busy. Waiting to be served you are greeted by acquaintances and friends, with cheery 'hello, how are you?'. You have a chat, talk about your day, and the issues you are having at work. Its loud, hard to hear within the small groups formed. In the group of five people I am with, the attendees question: we are having this problem, do you? Yes. We do this... what are you thinking of doing? Do you have a structured talent mobility program? Do you offer the family support? Is there resistance to this? (Narrative 3, Observation, Tea break after seminar, 2012).

Second, the narrative shows the breaks often being used to catch up with acquaintances and friends both on a personal and professional level. This sociability at the Expat Show is both a form of networking and a form of benchmarking. As McDowell's work on gender in merchant banks suggests, 'investment banking is, by 
Cite as: Cranston S, 2014, "Reflections on doing the Expat Show: performing the Global Mobility 19 Industry" Environment and Planning A 46(5) 1124 - 1138, doi:10.1068/a4624

definition, about networking and developing personal contacts' (McDowell, 1997 191). She suggests that the expansion of work into leisure, and thus into spaces of leisure results in (gendered) work being carried out as a social activity in bars and restaurants. However, this sociability as work also happens at work events such as the trade show. It is through this that we can see how the Expat Show enables the practice of 'softer' forms of knowledge, the 'knowledges which are transmitted through gossip and small talk which often prove surprisingly important' (Thrift, 2005 6). This is 'buzz,' that is knowledge practised through face-to-face (F2F) contact (Storper and Venables, 2004; Bathelt and Schuldt, 2010).

This networking is also a way of benchmarking. As Schuldt and Bahelt argue trade fairs enable the circulation of business knowledge as 'personal contact between people continues to be a decisive mechanism of circulating news, exchanging knowledge and solving problems' (2011 7). For example, the attendees in the narrative compare aspects of their expatriate programmes, with each other, seeking out and negotiating a common solution, for example trying to ascertain whether family support is an industry norm. This can be seen as part of the general advantages of $\mathrm{F} 2 \mathrm{~F}$ as an 'efficient technology of transaction under these circumstances, by permitting a depth and speed of feedback that is impossible in other forms of communication' (Storper and Venables, 2004 354). It allows for immediate benchmarking about what services should be offered as part of a talent mobility programme, in the case of the narrative whether family support should be seen as part of this. Therefore, this is a different way in which benchmarking can operate through the 'drawing up of possible world states.' It is a practice of knowledge that works on a more personal and social scale. 
Cite as: Cranston S, 2014, "Reflections on doing the Expat Show: performing the Global Mobility 20 Industry" Environment and Planning A 46(5) 1124 - 1138, doi:10.1068/a4624

The Expat Show is a space in which we can see how benchmarking operates in practice. Here, benchmarking can be seen as a knowledge practice- a way in which knowledge is circulated at the trade show. The narratives illustrate that this practice of knowledge takes on different forms through people and objects, for example through the projection of PowerPoint, through the talk of presenters, through the chat of the attendees. Returning to Barnes, he explores how George Chisholm's Handbook of Commercial Geography 'performed economic geography: it not only made present a representation of economic geographical reality, but made the reality itself' (Barnes, 2002 500). Following this, the knowledge that is practised and transferred at the Expat Show is not merely a representation, but is performative.

\subsection{At the Show: Talent Management}

In the basement of the hotel, downstairs and away from the exhibitors. It is stifling hot. The half-full audience is told 'we will focus on a set of key messages, best practices and role plays so you will have examples of what is important today in talent management.' In this seminar, we are told that the most important aspect to understanding and training the 'talent' within transnational organisations is intercultural awareness. To do this, the audience is told that organisations must assess the intercultural skills of an individual before they go abroad. In this case an interactive assessment tool should be used, like the one that this organisation offers that looks at risk taking, communication and team playing and comparing these characteristics to the norm in the country in which they are going to. The characteristics of talent management, we are told are the ones that 'ultimately fuelling success in expatriation.' (Narrative 4, Seminar by Director and IHRM Client, Cross-Cultural Management Services, 2010). 
Cite as: Cranston S, 2014, "Reflections on doing the Expat Show: performing the Global Mobility 21 Industry" Environment and Planning A 46(5) 1124 - 1138, doi:10.1068/a4624

Here, the cross-cultural training company begins to draw up the ideal characteristics of a talent management programme, one which assesses how well the expatriate can adapt to living in a different culture. While on the surface we can suggest that the GMI is involved in the transactional management of expatriates, what the narrative begins to illustrates is how the Expat Show provides us with a space through which we can understand how the transactional becomes part of the strategic, legitimising the need for GMI within IHRM processes.. This is done through talent management.

The war for talent, a concept developed by management consultants McKinsey in the late 1990s, refers to the so-called global shortage of highly-skilled workers and the subsequent challenge that transnational organisations face to attract, develop and retain the workforces that they require (Michaels et al., 2001). Within organizations, the war for talent becomes operationalized through talent management. Doing an expatriate assignment is increasingly understood as a training tool to develop a talented workforce, for example by developing the skill of being able to work across cultures (Dowling et al., 2008; PriceWaterhouseCoopers, 2010). Events such as trade shows are arenas in which this knowledge of how to strategically manage expatriates can be circulated to IHRM professionals. However, as Lewis and Heckman note there is "a disturbing lack of clarity regarding the definition, scope and overall goals of talent management" (2006 139). Within IHRM there remains a lack of consensus about what talent is, how organizations can develop it and how these theoretical ideas can be practised (Collings and Mellahi, 2009). This section will show first how Expat Show acts as space in which talent management is defined, and 
Cite as: Cranston S, 2014, "Reflections on doing the Expat Show: performing the Global Mobility 22 Industry" Environment and Planning A 46(5) 1124 - 1138, doi:10.1068/a4624

second the how the forms in which it is practised in transnational organisations are elucidated.

First, returning to Callon's calculative practices, after stage a), the second and third stage is to 'b) hierarchize and rank these world states; c) identify and describe the actions required to produce each of the possible world states' (Callon, 1998 260). The seminar in the hotel basement presented in narrative four shows how this works in practice through producing understandings of what an 'successful' expatriate assignment management programme looks like. This is the drawing up of possible states of talent management and the ranking of the ideal- the characteristics of the expatriate that need to be addressed for them to be considered 'talented.' The presenter of the talk frames these characteristics as being part of an ideal talent management programme within transnational organizations. The speaker also tells the audience how this ideal state can be achieved- by using this particular company's services, the particular interactive assessment tool that will in turn quantify this skill. This is how we can see that in creating an idealised notion of expatriate management within talent management, the GMI sells and regulates understandings of what talent management is. This knowledge is not only practised through the seminars, but is also in other parts of the Expat Show.

I squeeze past the brightly coloured images of globes, smiling businesspeople and families from across the globe, the vendors chatting to current and potential new clients, to find a stall where someone is free to talk to them. I get asked: 'Do you want a cupcake to go with that coffee? This the stall of a Relocation Management Company and a Business Development Manager is handing out freebies. We talk in general about the Expat Show, he asks me which seminars I have been to and whether they were any good. The general chat is interspersed with my questions. The show for him has been really good for networking- the main reason they go is to make 'new 
Cite as: Cranston S, 2014, "Reflections on doing the Expat Show: performing the Global Mobility 23 Industry" Environment and Planning A 46(5) 1124 - 1138, doi:10.1068/a4624

contacts' to follow up on after the show. Talent Management is a 'hard one,' expatriate management is changing; some of it is talent management. What we do as a company in relation to talent management? Well we do "the usual stuff" in expatriate management, "here I'll give you this brochure to show you." (Narrative 5, Chat with Business Development Manager, Relocation Management Company, 2011).

Ideas about talent management are also conveyed directly by the vendors at the stalls in the Expat Show. As narrative 5 shows, this carried out through ideas of the successful expatriate, which work through a combination of objects and people. In this case, ideas about success are generated implicitly through the images of the globe and happy smiling expatriates. These visual aids are also supplemented by text on advertising banners, highlighting the services that are offered, inviting the passer-by to connect images of success to services provided. These images help to draw up the 'potential states' of talent management, ideas which become more explicit through the advertising brochures you are invited to take away which illustrate the 'best practices' in managing talent. The stalls, where the direct sell happens, work to practice knowledge about what talent management programmes will look like. Again, the vendors 'identify and describe' how to achieve this state of talent management- this is through using their services as the invitation to look at the brochure begins to highlight.

Second, following McCann, in his context of a global ethnography of urban policy, we can suggest that the trade show acts as a 'site of persuasion' (2011 116). The attendees of the expat show can be persuaded to take on a particular form of talent management in their organisation, by comparing themselves to others there. This means we can see the practices of knowledge at the Expat Show as being performative in three interlinking ways. First, the practices of knowledge at the Expat 
Cite as: Cranston S, 2014, "Reflections on doing the Expat Show: performing the Global Mobility 24 Industry" Environment and Planning A 46(5) 1124 - 1138, doi:10.1068/a4624

Show performs the importance of talent management for expatriate management which regulates understandings of what talent management looks like. For example, returning to seminar in the basement in narrative 4 , the speakers are articulating the characteristics to measure to determine a 'talented' employee- risk taking, communication and team playing. These characteristics become understood as part of the intercultural skills required for a talented employee, and measuring them as part of a talent management programme. Second, through the practice of benchmarking, the Expat Show can be seen as a space of business education (Hall, 2009), which is both facilitated by specialist service providers and by peers. The benchmarking of best practices within talent management means that organisations may change their expatriate policies to fit the norm, as the Expat Show provides them with evidence of this as a best practice. This performs the knowledge into practice within organisations. It is a way through which talent management can be made 'manifest' (c.f. Larner and Le Heron, 2002 763). Both of these ways in which knowledge is performative at the Expat Show illustrate that the show does not merely act as a space in which the GMI reports the latest Global Mobility trends. To borrow MacKenzie's (2006) words, the Expat Show acts as an engine not a camera. Rather than reporting knowledge about the Expat Show, knowledges are driven into being.

In so doing, the Expat Show also performs a need for the GMI within talent management practises- this is the third way in which the knowledge at the Expat Show is performative. The practices of knowledge about talent management begin to illustrate what Thrift (2005) may describe as a cultural circuit of capital, the performative element of knowledge in the economy. The demand for global mobility services is produced through practices that involve the creation of a problem, and its solution is offered through the expertise of the GMI company. In both narratives four 
Cite as: Cranston S, 2014, "Reflections on doing the Expat Show: performing the Global Mobility 25 Industry" Environment and Planning A 46(5) 1124 - 1138, doi:10.1068/a4624

and five, the idea of the successful expatriate is played upon as a way in which to rank ideal talent management programs. However, this works to produce certain understandings of how to implement talent management within organisations- by using the GMI's services. This illustrates how the practice of knowledge at the Expat Show both enacts certain forms of knowledge of talent management, while simultaneously reproducing them as being part of the GMI. This means that the Expat Show does not simply describe and outline vendor's services, but produces the desire for them- it is the apparatus through which talent management can become known (Mitchell, 2008). Therefore, it is in this way we can begin to suggest that the practices of knowledge at the Expat Show help to produce the GMI.

\section{Conclusions}

This paper has looked at the practices of knowledge at the Expat Show, arguing that this event simultaneously performs understandings of talent management into being, whilst performing a need for the GMI within talent management expatriate programmes. In doing so it presents a shift in thinking to looking at knowledge economies as 'bundles of practices and material arrangements always in the making' as opposed to a presumed given (Berndt and Boeckler, 2011 565). The Expat Show is a space that makes the GMI, rather than a space that merely represents it. This therefore illustrates the importance of researching multiple sites of the economy. In economic geography we need to consider more than the spaces of the organisation when we look at how the knowledge economy operates. The GMI is produced through its organisations' assistance of expatriates, its technical day-to-day role, and through its 'props,' its adverting brochures, its survey reports, its meetings with 
Cite as: Cranston S, 2014, "Reflections on doing the Expat Show: performing the Global Mobility 26 Industry" Environment and Planning A 46(5) 1124 - 1138, doi:10.1068/a4624

clients. But the industry is also produced through events like the trade show. In echoing Jones in the special issue on business travellers in Geografiska Annaler, the paper shows why 'there is a need to conceptualise the nature of business space beyond a focus on physical offices, factories, or other production facilities which are located in demarcated places or territories' (Jones, 2009 204). However, this paper has shown that we need to go further than just conceptualising what these spaces of the economy are, their design, location and production (for example McNeill, 2009). We also need to consider what happens within these spaces. Further research could look at the trade shows within different knowledge economies (Bathelt and Schuldt, 2010; Schuldt and Bathelt, 2011), the trade show industry itself more generally or different formats of trade shows such as e-fairs.

As the paper has shown, benchmarking works through the 'specific performances' (Gregson and Rose, 2000 434) of people and objects. By drawing on the pragmatic turn we see the importance of understand the role that people and objects play within the knowledge economy. Although we can critique this approach as not being able to determine the relative importance of specific performances of people and objects, it offers a more micro-scale, everyday approach that economic geography needs to engage with more directly. These knowledge practices are not just contained within the Expat Show, as talent management illustrates, they are performative. They are performative for fixing understandings of the woolly concept of talent management, performing specific understandings of talent management into organisations and most importantly performing a need for the GMI within IHRM processes. These practices and performances can be seen to be specific to this type of trade show.. It is through the circulation and performance of knowledge, as well as its 
Cite as: Cranston S, 2014, "Reflections on doing the Expat Show: performing the Global Mobility 27 Industry" Environment and Planning A 46(5) 1124 - 1138, doi:10.1068/a4624

packaging that the GMI produces a need and role for itself, gives itself a name, a direction, how it comes into being.

This means that research on the economy needs to think differently about methods. Despite research on knowledge economies arguing for the a need to reconfigure how we understand the economic as not being separate from culture (for example Du Gay and Pryke 2002), the way in which economic geography is practised often rehearses a distinction that separates the economy from the pragmatic. The corporate interview (Schoenberger, 1991), often the favoured cultural economic method, looks at what people say they do rather than examining what people do with regards to knowledge practices, missing an understanding of how knowledge is practised on the ground in spaces of the economy. As the paper has shown, the way in which knowledge is practised involves both people and objects. Participant observation enables us to understand not just what is contained within knowledge practices, but how knowledge is practised. It can show the experience of being there, that is taking part by going round the stalls talking to the vendors, talking with the other attendees, whilst simultaneously observing, overhearing and writing notes. Writing this as a narrative is a writing of the economy that brings together what goes on at the Expat Show, with how it goes on.

This approach to understanding the economic is criticised by some for not asking the big political questions (Berndt and Boeckler 2011). However, as Berndt and Boeckler highlight the contribution of this approach is that it permits 'an engagement with global network capitalism without losing sight of the heterogeneity and differentiation of capitalist practices' (2011 566). The (knowledge) economy is continually practiced and performed in different ways and in different places, it is always in the making. As Thrift (2005 6) highlights, the cultural circuit of capital 
Cite as: Cranston S, 2014, "Reflections on doing the Expat Show: performing the Global Mobility 28 Industry" Environment and Planning A 46(5) 1124 - 1138, doi:10.1068/a4624

'which is intended to keep capitalism surfing along the edge of its own contradictions'- it is a perpetual project. So while some critique the use of performativity in the economic by pointing to its 'partiality and ephemeral [quality]' (Mirowski and Nik-Khah in Christophers 2012 2544), this is because the economy operates in practice. It is through the contradictions of the economy that talent management and the GMI itself is made, remade, changed and contested. The performativity of knowledge about talent management at the Expat Show is imbued with putting the GMI on the talent management agenda, but like the way in which this is practised at show, it is heterogenetic and differentiated.

\section{Acknowledgements}

I would like to thank the show organisers for giving me permission to use the show for my research. I am indebted to all those who provided feedback on previous drafts of this paper, especially Dan Swanton, as well as the three anonymous referees. This research was supported by ESRC PhD studentship.

\section{References}

Barnes, T J, 2008, "Making Space for the Economy: Live Performances, Dead Objects and Economic Geography" Geography Compass 2(5) 1432-1448.

Barnes, T J, 2002, "Performing economic geography: two men, two books, and a cast of thousands" Environment and Planning A 34(3) 487-512.

Barnes, T J, Peck, J, Sheppard, E, and Tickell, A, 2007, "Methods matter: transformations in economic geography", in Politics and Practices in Economic Geography Eds A Tickell, E Sheppard, J Peck, and T J Barnes (Sage, London).

Bathelt, H and Schuldt, N, 2010, "International Trade Fairs and Global Buzz, Part I: Ecology of Global Buzz” European Planning Studies 18(12) 1957-1974.

Bathelt, H, Malmberg, A, and Maskell, P, 2004, "Clusters and knowledge: local buzz, global pipelines and the process of knowledge creation" Progress in Human Geography 28(1) 31-56. 
Cite as: Cranston S, 2014, "Reflections on doing the Expat Show: performing the Global Mobility 29 Industry" Environment and Planning A 46(5) 1124 - 1138, doi:10.1068/a4624

Beaverstock, J V, 2002, "Transnational elites in global cities: British expatriates in Singapore's financial district" Geoforum 33(4) 525-538.

Beaverstock, J V, 2005, "Transnational elites in the city: British highly-skilled intercompany transferees in New York city's financial district" Journal of Ethnic and Migration Studies 31(2) 245-268.

Berndt, C and Boeckler, M, 2009, "Geographies of circulation and exchange: constructions of markets" Progress in Human Geography 33(4) 535-551.

Berndt, C and Boeckler, M, 2011, "Geographies of markets: Materials, morals and monsters in motion" Progress in Human Geography 35(4) 559-567.

Beunza, D and Stark, D, 2004, "Tools of the trade: the socio-technology of arbitrage in a Wall Street trading room" Industrial and Corporate Change 13(2) 369-400.

Callon, M, 1998 Laws of the Markets (Wiley-Blackwell).

Christophers, B, 2012, "Games and prizes in the economic (and geographical?) performance of markets: Nobel, Shapley, and Roth" Environment and Planning A 44(11) 2542-2545.

Coe, N M and Bunnell, T, 2003, “'Spatializing' knowledge communities: towards a conceptualization of transnational innovation networks" Global Networks 3 437456.

Collings, D G and Mellahi, K, 2009, "Strategic talent management: A review and research agenda" Human Resource Management Review 19(4) 304-313.

Conradson, D, 2003, "Doing organisational space: practices of voluntary welfare in the city" Environment and Planning A 35 1975-1992.

Cook, I (2005) Participant Observation, Methods in Human Geography: A guide for students doing a research project EDs. R.Flowerdew and D. Martin. (Harlow, Essex, Pearson Education) 167-186

Crang, P, 1994, "It's showtime: on the workplace geographies of display in a restaurant in southeast England" Environment and Planning D-Society \& Space 12 675-704.

Dowling, P J, Festing, M, and Engle, A D, Sr, 2008 International Human Resource Management Fifth Edition (Centage Learning EMEA, Andover, Hampshire).

du Gay, P. and M. Pryke (2002) Cultural Economy: cultural analysis and commercial life. (London; Thousand Oaks, California; New Delhi, Sage Publications)

Faulconbridge, J R, 2007, "Exploring the role of professional associations in collective learning in London and New York's advertising and law professionalservice-firm clusters" Environment and Planning A 39(4) 965-984.

Faulconbridge, J R, 2010, "Global architects: learning and innovation through communities and constellations of practice" Environment and Planning A 42(12)

Cite as: Cranston S, 2014, "Reflections on doing the Expat Show: performing the Global Mobility Industry" Environment and Planning A 46(5) 1124 - 1138, doi:10.1068/a4624 
Cite as: Cranston S, 2014, "Reflections on doing the Expat Show: performing the Global Mobility 30 Industry" Environment and Planning A 46(5) 1124 - 1138, doi:10.1068/a4624

$2842-2858$.

Gertler, M S, 2003, "Tacit knowledge and the economic geography of context, or The undefinable tacit of being (there)" Journal of Economic Geography 3 75-95.

Gregson, N, 2009, "Material, Literary Narrative and Cultural Economy: Primo Levi and the industrial short story" Journal of Cultural Economy 2(3).

Gregson, N, 2011, "Performativity, Corporeality and the Politics of Ship Disposal" Journal of Cultural Economy 4(2) 137-156.

Gregson, N and Rose, G, 2000, "Taking Butler elsewhere: performativities, spatialities and subjectivities" Environment and Planning D-Society \& Space 18 $433-452$.

Hall, S, 2009, "Ecologies of business education and the geographies of knowledge" Progress in Human Geography 33(5) 598-618.

Hall, S, 2007, "Geographies of business education: MBA programmes, reflexive business schools and the cultural circuit of capital" Transactions of the Institute of British Geographers 33(1) 27-41.

James, A, Martin, R L, and Sunley, P, 2007, "The Rise of Cultural Economic Geography", in Critical Concepts in Economic Geography: Volume IV, the Cultural Economy (Routledge, London), pp 3-18.

Jones, A, 2009, “Theorizing Global Business Spaces" Geografiska Annaler Series BHuman Geography 91(3) 203-218.

Jones, A and Murphy, J T, 2011, "Theorizing Practice in Human Geography: foundations, challenges and possibilities " Progress in Human Geography 35(3) $366-392$.

Larner, W and Le Heron, R, 2002, "The spaces and subjects of a globalising economy: a situated exploration of method" Environment and Planning D-Society \& Space 20(6) 753-774.

Lewis, R E and Heckman, R J, 2006, "Talent management: A critical review" Human Resource Management Review 16(2) 139-154.

MacKenzie, D, 2006 An Engine, Not a Camera: How Financial Models Shape Markets (The MIT Press, Cambridge, Mass; London).

Maskell, P, Bathelt, H, and Malmberg, A, 2006, "Building global knowledge pipelines: The role of temporary clusters" European Planning Studies 14(8) 9971013.

McCann, E, 2011, "Urban policy mobilities and global circuits of knowledge: Toward a research agenda" Annals of the Association of American Geographers 101(1) $107-130$.

McDowell, L, 1997 Capital Culture: Gender at work in the City (Wiley-Blackwell,

Cite as: Cranston S, 2014, "Reflections on doing the Expat Show: performing the Global Mobility Industry" Environment and Planning A 46(5) 1124 - 1138, doi:10.1068/a4624 
Cite as: Cranston S, 2014, "Reflections on doing the Expat Show: performing the Global Mobility 31 Industry" Environment and Planning A 46(5) 1124 - 1138, doi:10.1068/a4624

Oxford, UK; Malden, Massachusetts).

McMorran, C, 2012, "Practising workplace geographies: embodied labour as method in human geography" Area 44(4) 489-495.

McNeill, D, 2009, "The Airport as a Business Space" Geografiska Annaler Series BHuman Geography 91(3) 219-228.

Michaels, E, Handfield-Jones, H, and Axelrod, B, 2001 The War for Talent (Harvard Business School Press, Boston).

Millar, J and Salt, J, 2008, "Portfolios of Mobility: the movement of expertise in transnational corporations in two sectors- aerospace and extractive industries" Global Networks 8(1) pp. 25-50.

Mitchell, T, 2008, “Rethinking Economy” Geoforum 39(3) 1116-1121.

O'Reilly, K, 2005 Ethnographic Methods (Routledge, London, New York).

PriceWaterhouseCoopers, 2010, "Talent Mobility 2020: The next generation of international assignments", pwc.com/managingpeople2020.

Schoenberger, E, 1991, "The Corporate Interview as a research method in economic geography" Professional Geographer 43(2) 180-189.

Schuldt, N and Bathelt, H, 2011, "International Trade Fairs and Global Buzz. Part II: Practices of Global Buzz" European Planning Studies 19(1) -22.

Schwartzmann, H.B, 1993 Ethnography in Organizations (SAGE Publications, Newbury Park, London, New Delhi).

Storper, M and Venables, A J, 2004, "Buzz: face-to-face contact and the urban economy" Journal of Economic Geography 4(4) 351-370.

Swanton, D, 2013, “The steel plant as assemblage” Geoforum 44 282-291.

Thrift, N, 2005 Knowing Capitalism Ed M Featherstone (Sage Publications, London; Thousand Oaks; New Delhi).

Van Maanen, J, 2011 Tales of the Field: On writing ethnography, (University of Chicago Press, Chicago)

Walsh, K, 2006, “'Dad says I'm tied to a shooting star!' Grounding (research on) British expatriate belonging" Area 38(3) 268-278.

Yeung, H W-C, 2003, "Practicing New Economic Geographies: A Methodological Examination" Annals of the Association of American Geographers 93(2) 442-462. 